\title{
Avalokiteśvara in Tibetan Buddhist art of the Later spread (Tib. phyi dar) of the Dharma. Image classification proposal, part 1.
}

\author{
Joanna GRELA
}

\begin{abstract}
According to traditional Buddhist narratives and popular beliefs, Tibetans are a people chosen by Avalokiteśvara. Therefore, his worship and multitude, as well as diversity of his images are quite common both in temples and public areas. Unlike the widespread analyses where the Bodhisattva has been treated as a peaceful tutelary deity, and classifications of its images have been based on morphological features (i.e. the number of hands, heads, etc.) or by artistic styles and techniques. This paper proposes another approach by grounding images in Tantric Buddhism models used locally. In the first part of the article, the images of Avalokiteshvara are inscribed in the bodyspeech-mind models as well as the external, secret and the first of the three internal aspects of the Three Refuges, also known as the Three Jewels, which covers a much wider set of iconographic material than usually considered.
\end{abstract}

Keywords: Avalokiteśvara, maṇi mantrā, Three Jewels, Three Roots, Three Refuges, Tibetan art

Joanna GRela a Tibetologist, professor at the Jagiellonian University, employed at the Centre for Comparative Studies of Civilisations. Her research interests include Tibetan traditions and contemporary Buddhist cultures. She is the author of two monographs: Mahakala. The Six-Armed Guardian Deity in Tibetan Buddhism, Krakow 2005; Foundations of the Religious Culture of Tibet. Entangled History, Krakow 2015, several dozens of scientific articles, a dozen of extensive entries on the philosophy of Buddhism in The Universal Encyclopaedia of Philosophy and numerous translations from the Tibetan language.

E-MAIL: j.grela@uj.edu.pl 


\section{Introductory remarks}

Discussing "Buddhist art" or "Tibetan art" we tend to use European labels, whereas Buddhist artefacts, which we call "pieces of art", appear to be mostly craftwork, evidenced by both linguistic analysis and the formal features. Until the last century Tibetan language and perhaps most languages of Asian countries where Buddhism was present, did not have an equivalent term for "art". To use an example from Tibetan, the compound bzo rig pa, equivalent to Sanskrit silpa, consists of the verb "to make", "to manufacture" (bzo ba), and the noun "knowledge". Therefore, "craft" seems to be the closest European analogy. "Painting" is literally "drawing deities" (lha 'bri) in Tibetan, "sculpture" creating shapes ('jim bzo), "sculptor" is somebody "making” in stone ( $r d o b z o b a$ ), in wood (shing $b z o b a$ ), etc. Furthermore, those usually not signed creations were imitative, predictable, and canonical. Not made to stimulate the aesthetic senses, but religious experiences they were supposed to inspire and foster positive impressions in the stream of consciousness, to calming one down, stabilise the mind, and not trigger emotions. The consecrated images were additionally perceived as carriers of power, or blessing. Their impact was supposed to come from their sacral anchoring guaranteed by compliance with canon. Although further in my paper, I will use common terms like "art" and "pieces of sacral art" ${ }^{1}$, the above comments are the initial premise meant to be added to the pool of images of Avalokiteśvara, a much wider spectrum of objects, including utilitarian ones. The second point assumes emic perspective and applies a classifying model for various popular phenomena in Tibetan Buddhism.

\section{Avalokiteśvara in Tibet. Body, speech, and men- tal aspects.}

An important role of Bodhisattva Avalokiteśvara in Buddhism, especially in Mahayana, is unquestionable, which is evidenced by both the number

1 Pursuant to the classical differentiation by Peter Fingesten 1951: sacral art is canonical, liturgical, anonymous, and didactic, limited by religious rules and intended solely for the purpose of worship, while religious art is inspired, free, and individualised, not reduced to realising the goals of worship. 
of canonical texts, where he ${ }^{2}$ appears (Saddharma Puṇdarika, Avatamsaka, Kāraṇdavyūha, Prajñāpāramitāhṛdaya, and many other sūtras), and his depiction in fine arts. Statistical analysis of Chinese art shows that, next to Amitabha, he became most popular during the rule of the Tang dynasty ${ }^{3}$. Earlier, however, with the growing popularity of Avatamsakasūtra in East Asia, ancient Mahayanist concepts identified Vairocana as an idealised ruler during the later period of Northern Dynasties, climaxing in the 8th century, i.e. in the era when Buddhism reached the Tibetan Plateau. The cult fell into a wider, almost pan-Asian worship of monumental Buddhas (Skt. brihad bud$d h a$ ), culminating in the mid 8th century with the construction of the Tōdaiji temple complex in Japan. The ornamentation in the first Tibetan Buddhist temple in Samye (Tib. bsam yas; 8th century), sanctuaries of the first or early spread (snga dar) of the Dharma, and parallelly preserved texts ${ }^{4}$ depict Vairocana as the main worshipped deity. As Kapstein reports, "the association of Vairocana with the royal cult appears to have endured in West Tibet well into the second millennium" ${ }^{5}$ However, in time, in many Buddhist areas, this worship (and in the Indianized kingdoms of South-eastern Asia, the worship of a Hindu god-king) was replaced by the worship of a ruler believed to be an incarnation of Avalokiteśvara. ${ }^{6}$ Similarly in Tibet, the Bodhisattva of Compassion finally outclassed Vairocana and other figures of the Buddhist pantheon in popularity and number of depictions.

As claimed by many Mahayana legends, Avalokiteśvara (Tib. spyan ras gzigs; an equivalent of a shortened name Avalokita ${ }^{7}$ ) appeared on Earth as a light ray from the right eye of the Amitābha Buddha to help others with his earthly incarnations. Interventions of this Bodhisattva on the Tibetan Plateau were to begin as early as prehistoric times, but the earliest known texts on the subject come from the period of the Late spread of the Dharma, like Mani bka' 'bum, traditionally believed to be a text from the 7 th century, but dated back by researchers to approx. 12th century. According to the main

${ }^{2}$ In Indian and Tibetan Buddhism Avalokiteśvara is depicted as a male figure, therefore a masculine pronoun.

3 Yü.1994: 152.

4 PT 7a, PT 240.

5 Kapstein, 2000: 61.

6 Cf. God and King: The Devaräja Cult in South Asian Art. 2005.

7 In the manuscripts, written in Tibetan from Dunhuang, Avalokiteśvara is referred to as spyan ras gzigs dbang phyug. In the 'Later spread of the Dharma', the Tibetan equivalent of his name appears abbreviated to spyan ras gzigs and reflects the Sanskrit form "Avalokita". 
narrative theme of the anthropogenic myth about the Tibetan protoplast, in the times of Śakyamuni Buddha, Avalokiteśvara, abiding in his pure realm Potala (Skt. potalaka), looked at the Land of Snows, and saw there many beings lost in the dark, unfamiliar with the Dharma, falling into increasingly lower worlds without a chance for liberation. Driven by compassion, he sent his emanation there as a king of monkeysand was immersed in meditation in the area controlled by demons (Skt. rākșasa, Tib. srin po) and animals. Upon seeing him, one of the female demons began assuming various forms to seduce him, but he remained unmoved until she threatened to start killing and eating ten thousand beings a day if he did not surrender and become a couple. Bodhisattva of Compassion couldn't allow that and, ultimately, he conceived the first Tibetans with the demoness. Monkey-Bodhisattva (Tib. pha sprel rgan byang chub sems $d p a^{\prime}$ ) the first bodily form of Avalokiteśvara in Tibet was to teach his children, the first Tibetans, moral principles and farming ${ }^{8}$.

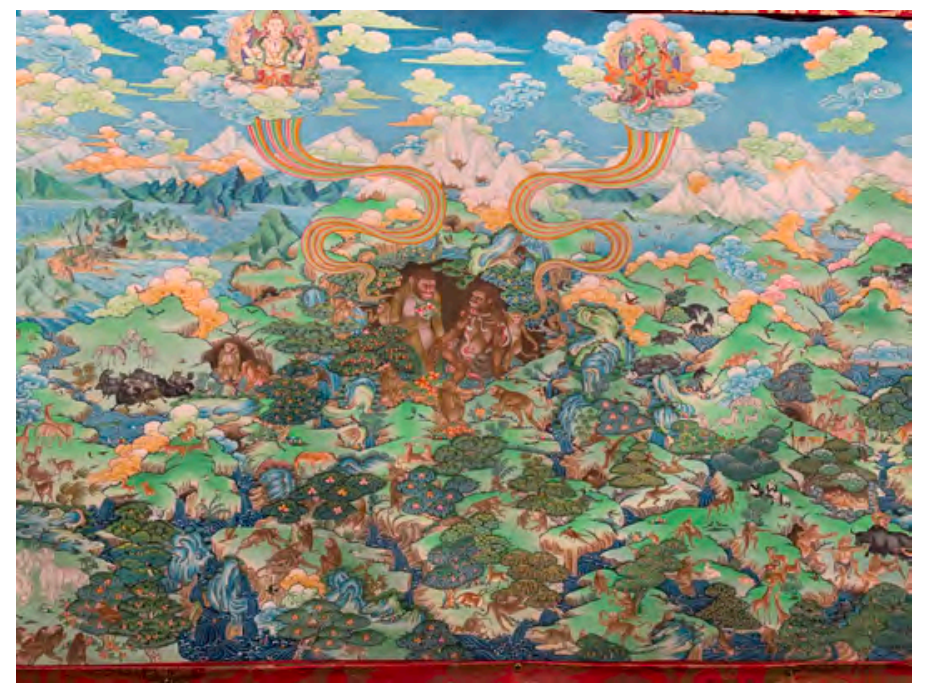

Photo 1. "The Origin of Tibetans", The Qinghai Tibetan Medicine Museum in Zi ling (Chin. Xining). Photo by Joanna Grela.

Many versions of this story exist ${ }^{9}$, the individual scenes shown on temple frescoes and painted rolls (thang kha) may differ. The painted version presented above is part of a modern piece of collective art, 618 meters long,

8 Maṇi bka' 'bum. 1991: 79-81b.

9 See the list of literary sources in: Bsod nams rgyal mtshan (1312-1375), 1966: xviii. 
2.5 meters wide, completed in 1999. It's worth mentioning that in this depiction - which is rare - the partner of Avalokiteśvara is Tārā (sgrol ma). This might be a reference to the myths about one of the main wives of an important Tibetan ruler from the 7 th century; this theme will be elaborated on below.

In regards to depicting Avalokiteśvara as a monkey, an interesting comparative path is suggested by André Segarra, pointing to the worship of supernatural beings, presented in this animal form in India (Hanuman), later in China (Hou wang) and Tibet ${ }^{10}$. Let me add, that in ca. $15^{\text {th }}$ century, monkeyBodhisattva received his proper name in Tibet: Halumada (sometimes Halumezu).

From the perspective of the legends that were passed on, supported by Mani bka' 'bum who established the main myths on the patronage of Avalokiteśvara over Tibet and popularised the worship of this figure, another trace of information connected to this Bodhisattva is an event usually dated at around $433 \mathrm{CE}$, when several objects of miraculous power, supposedly connected to Avalokiteśvara, fell from the rainbow onto the roof of the royal Yumbu Lhagang palace in Central Tibet. One of them was a box with Kärandavyūhasūtra ${ }^{11}$, an important text, establishing, among others, the practise of reciting the six-syllable mantrā (Skt. om maṇi padme hüm, Tib. om maṇi padme hung), which is the most popular mantrā formula in Tibet, inscribed, e.g., in stones by the road, commonly known and chanted. In the art depicting this incident, a rainbow usually appears, connecting the sky with the palace roof; the figure of Avalokiteśvara himself is not shown, so I excluded those images.

The next intervention of Avalokiteśvara in the Tibetan Highlands, massively represented in art, is connected with king Songtsen Gampo (srong btsan sgam po) from the first half of the 7 th century. Although no evidence for him being identified with Bodhisattva during his rule and in the next three centuries ${ }^{12}$, the collective Tibetan myth, popularised in the course of the 'Later spread of the Dharma', retrospectively appointed him Avalokiteśvara's incarnation. He was to appear in his mother's womb as a thumb-sized child, transferred there by a light ray emanating from the right eye of the

${ }^{10}$ Segarra 2007.

${ }^{11}$ Mani bka' 'bum. 1991: 189b.

${ }^{12}$ Only late-medieval literary sources (e.g. Mani bka' 'bum) and historical sources (e.g. Bsod nams rgyal mtshan (1312-1375), Rgyal rabs gsal ba'i me long) idealise Songtsen Gampo and identify him with the Bodhisatva of Compassion. 
Bodhisattva. ${ }^{13}$ The diffusion of the myth idealising the ruler as Avalokiteśvara, without referring to expansionist campaigns, bloody conquests, and ambushes ${ }^{14}$, coincided with the initial stage the 'Later spread of the Dharma' in Tibet which was particularly connected to the Mahayana ideals of compassion from the Kadam school (Tib. bka' gdams) and took place after the fall of the Yarlung dynasty, at a time of political disintegration. Thus, I believe a deliberate popularisation of a unifying, resounding national myth by religious circles is most probable.

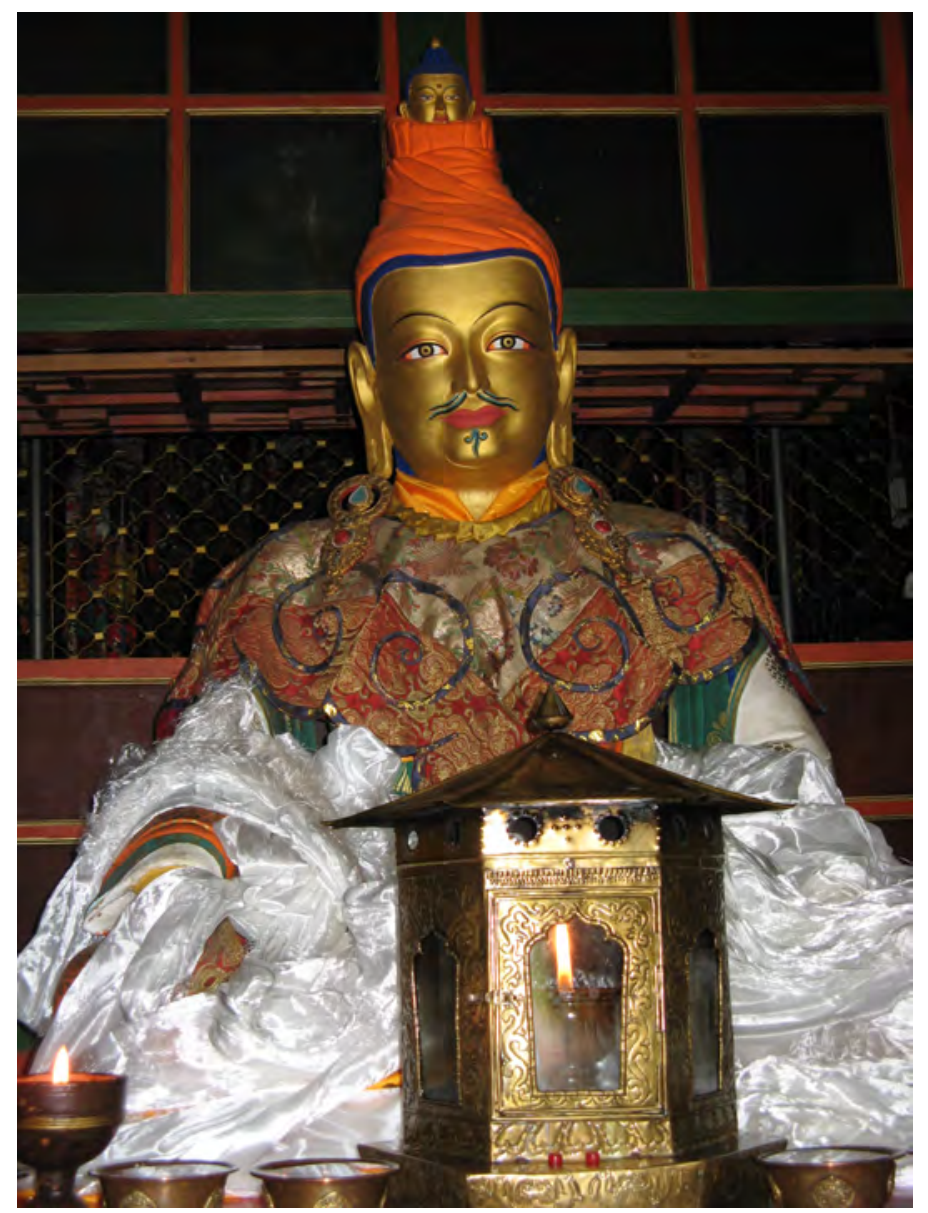

Photo 2. Songtsen Gampo's statue, Chongye Valley. Photo by Joanna Grela.

\footnotetext{
${ }^{13}$ Maṇi bka' 'bum. 1991: 190.

${ }^{14}$ Cf. Kollmar-Paulenz, 2014: 30-35.
} 
In Tibetan Buddhism the Three Refuges or the Three Jewels (Skt. Triratna, Tib. dkon mchog gsum) take outer, inner, and secret forms, where the last one consists of differentiating the three bodies (kaya, sku). In the preserved "Later spread of the Dharma" iconography, Songtsen Gampo is presented as a nirmānakāya, a human, a bodily incarnation of Avalokiteśvara (Skt. saṃbhogakāya). Sculptures and paintings portray Songtsen Gampo in a turban, crowned with the head of Amitābha (dharmakāya). This special sign - Buddha's presence above his head - was said to accompany the future ruler from birth.

The late-medieval Tibetan writings depict two of the ruler's wives, the Nepalese and Chinese princesses, as the incarnations of Tārā, the female form of compassion, born of two tears of Avalokiteśvara and incarnated on Earth to assist in the work of implanting the Dharma in the Land of Snows. As devoted Buddhists with their husband, Songtsen Gampo, they were supposed to contribute to the introduction of Buddhism in Tibet and contribute to building many chapels. Still, even though Songtsen Gampo, when conquering new lands and expanding the borders of his empire, must have encountered Buddhism in Khotan, as well as the Indian, Nepalese, and Chinese Buddhism, the sources do not question religious beliefs of the two wives, no early documents (inscriptions, Old Tibetan Annals ${ }^{15}$ or Old Tibetan Chroni$\left.\mathrm{cle}^{16}\right)$ mention the acceptance of Buddhism by the king, court, or subjects ${ }^{17}$. Rather, the king initiated a cultural revolution, which opened Tibet to Buddhism and, according to the sources from the era, built two or three chapels. Only the collective myth, about a thousand years old and still popular today, interpret the actions of the king as actions of Avalokiteśvara, who in the 7th century had a special plan for Tibet: establishing the state, protecting the Tibetans, and familiarising them with Buddhism ${ }^{18}$.

The Tantric Buddhism doctrine often systematises phenomena within another trichotomous division. i.e. of the three secret vajras which is an English rendering of Tibetan $r$ do rje gsang ba sum referring to the enlightened body, speech, and mind. The examples of Avalokiteśvara images in Tibetan

\footnotetext{
15 Version I: PT 1288, ITJ 0750, version II: Or8212.187; first French translation - J. Bacot, F. W. Thomas, Ch. Toussaint, Documents de Touen-Houang relatifs à l'histoire du Tibet, Paris 1940; English translation - The Old Tibetan Annals. An Annotated Translation of Tibet's First History, trans. B. Dotson, Wien 2010.

${ }^{16} \mathrm{PT} 1286$ and PT 1287.

${ }^{17}$ Cf. Macdonald, 1984: 129-141.

${ }^{18}$ Cf. Laird, 2007: passim.
} 
art presented so far, concern the first dimension. This group also includes the images of the lamas; bodies, believed to be incarnations (Skt. nirmānakāya; Tib. sprul sku) or emanations (nirmita; sprul pa) of this Bodhisattva, continuing "the great plan for Tibet": Dalai Lamas or Karmapas, to name just two of the many historical and modern attributions. ${ }^{19}$

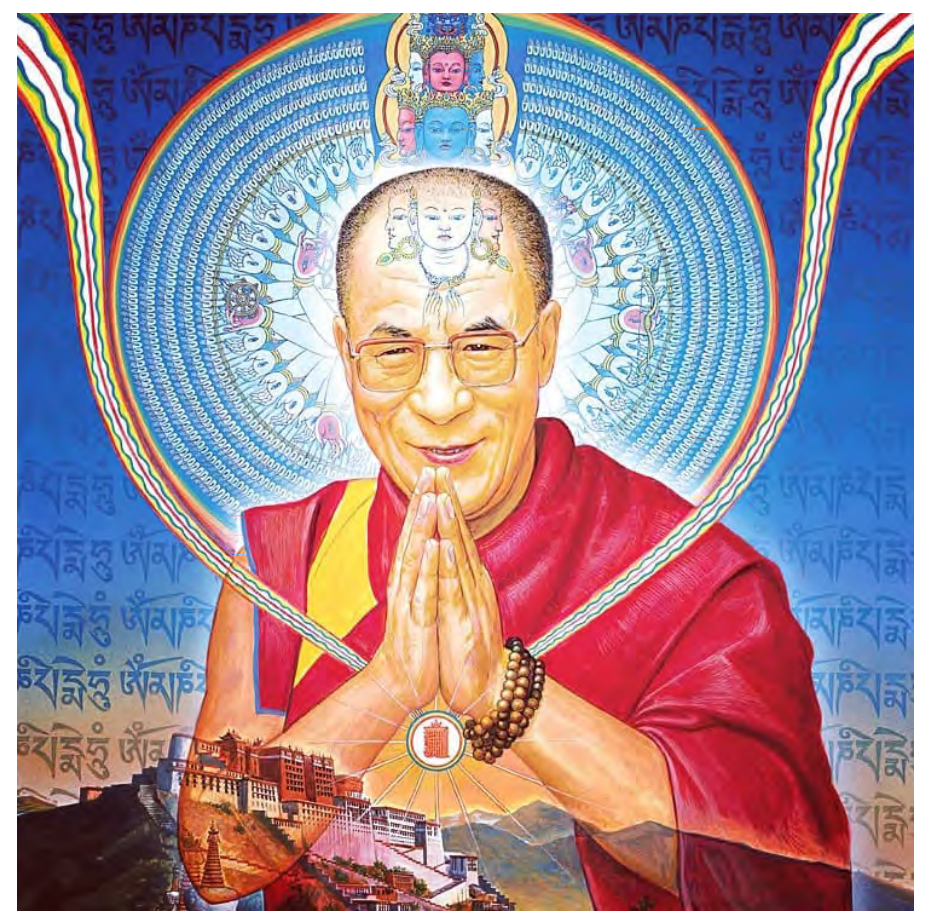

Photo 3. Dalai Lama depicted as Avalokiteśvara. Source: https: //bobthurman.com/buddhism-101-tibets-dalai-lama-ep-110/dal ai-lama-alex-grey/

As an illustration depicting lama as Avalokiteśvara, I chose the modern picture above, which in my opinion, covers all three "vajras" of the Bodhisattva. The body aspect (and at the same time, the lama in a model of three Tantric Roots) is a half-length portrait of the 14th Dalai Lama himself. The aspect of speech, or Dharma Jewel, is represented here by the six-syllable mantra $\bar{a}$ written in Tibetan alphabet, which fills the heavens in the painting, and possibly by the prayer beads (Skt. $m \bar{a} l \bar{a}$ ), wrapped around the left wrist of the Lama. The mind is present in the form of an 11-head and 1000-arm Avalokiteśvara as a meditational deity. American artist, Alex Grey (real name Alex

${ }^{19}$ Kapstein, 1992: 58. 
Velzy), inscribes the body of the Dalai Lama in the body of the Bodhisattva and his single human head becomes one of traditional eleven heads of deity. In the bottom left corner, the painting also depicts the Dalai Lama's residence in Lhasa, the eponymous Potala, built on a hill, believed to be the abode of the Bodhisattva of Compassion.

In accordance with Tantric models in the Avalokiteśvara images pool, I also include graphical depictions of his verbal dimension, i.e. mantrā, particularly occurring in outdoor art, street art of sorts. In fact, maṇi stones and maṇi walls (Tib. maṇi gdong) are a staple in the landscape of the Tibetan Plateau; they are quite numerous, rock-hewn, or painted. The most popular and visible among the many Avalokiteśvara's mantrās and dhäraṇis is the six-syllable one. Its syllables are often colourful: each allocated a colour corresponding to one of the six realms of samsāra. Not only by recitation, but simply the mere sight of these syllables is supposed to block the possibility of rebirth in samsāra, among other effects. Among the many forms that Avalokiteśvara can take there are also art depictions of six forms connected with six realms. In the table below I included the attributes and the colour of robes through which his standing figure is commonly recognized in iconography in the post mortem state (bar do).

\begin{tabular}{llll}
\hline Syllable & Colour (syllables/robes) & Attribute & Realm \\
\hline om & white & lute & gods \\
$m a$ & green & sword & demi-gods \\
$n i$ & yellow & staff and bowl & humans \\
pad & blue & book & animals \\
$m e$ & red & bowl of food and jewels & hungry ghosts \\
$h \bar{u} m$ & dark blue or black & flame or mirror & hells \\
\hline
\end{tabular}




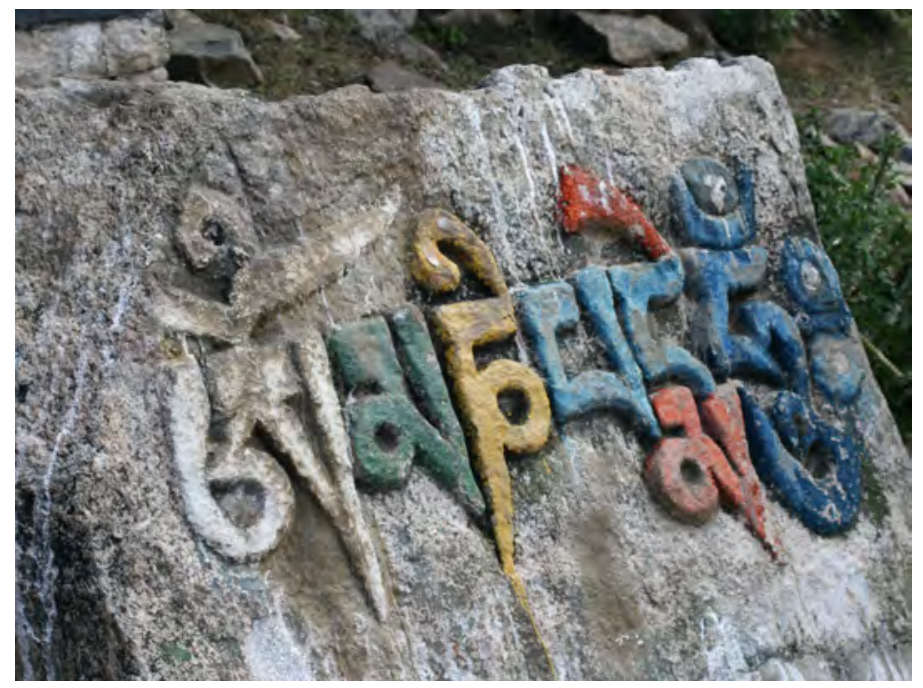

Photo 4. Mani stone in Lhasa. Photo by Joanna Grela.

Maṇi mantrās, regarded as the presence of Avalokiteśvara, are also represented by the objects of applied art, like outdoor as well as small, personal prayer wheels, with printed forms of the six syllables hidden inside and also decorated on the outside.

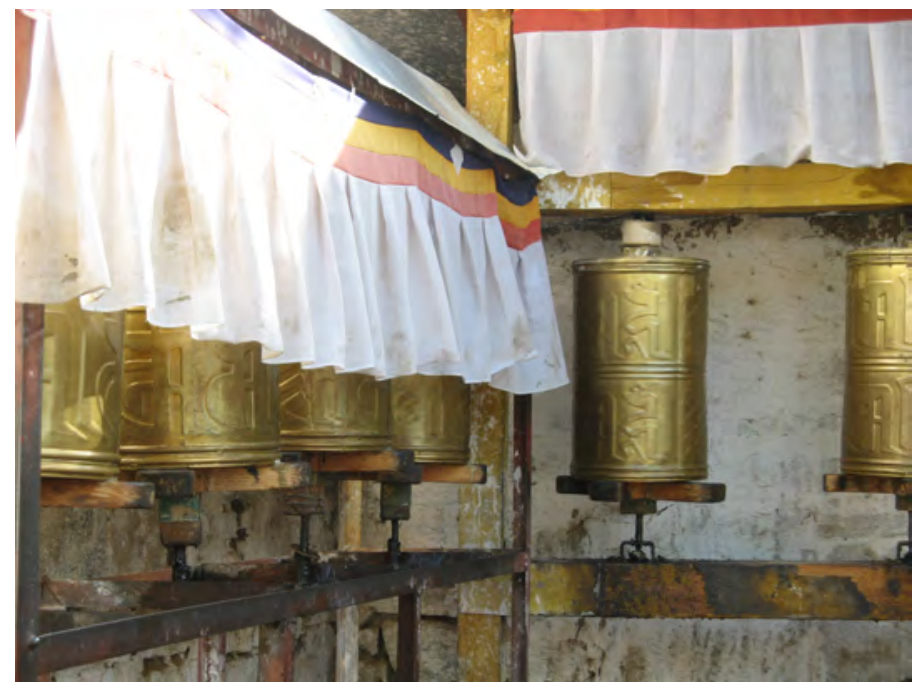

Photo 5. Outdoor prayer wheels at Drepung Monastery, Lhasa. Photo by Joanna Grela. 


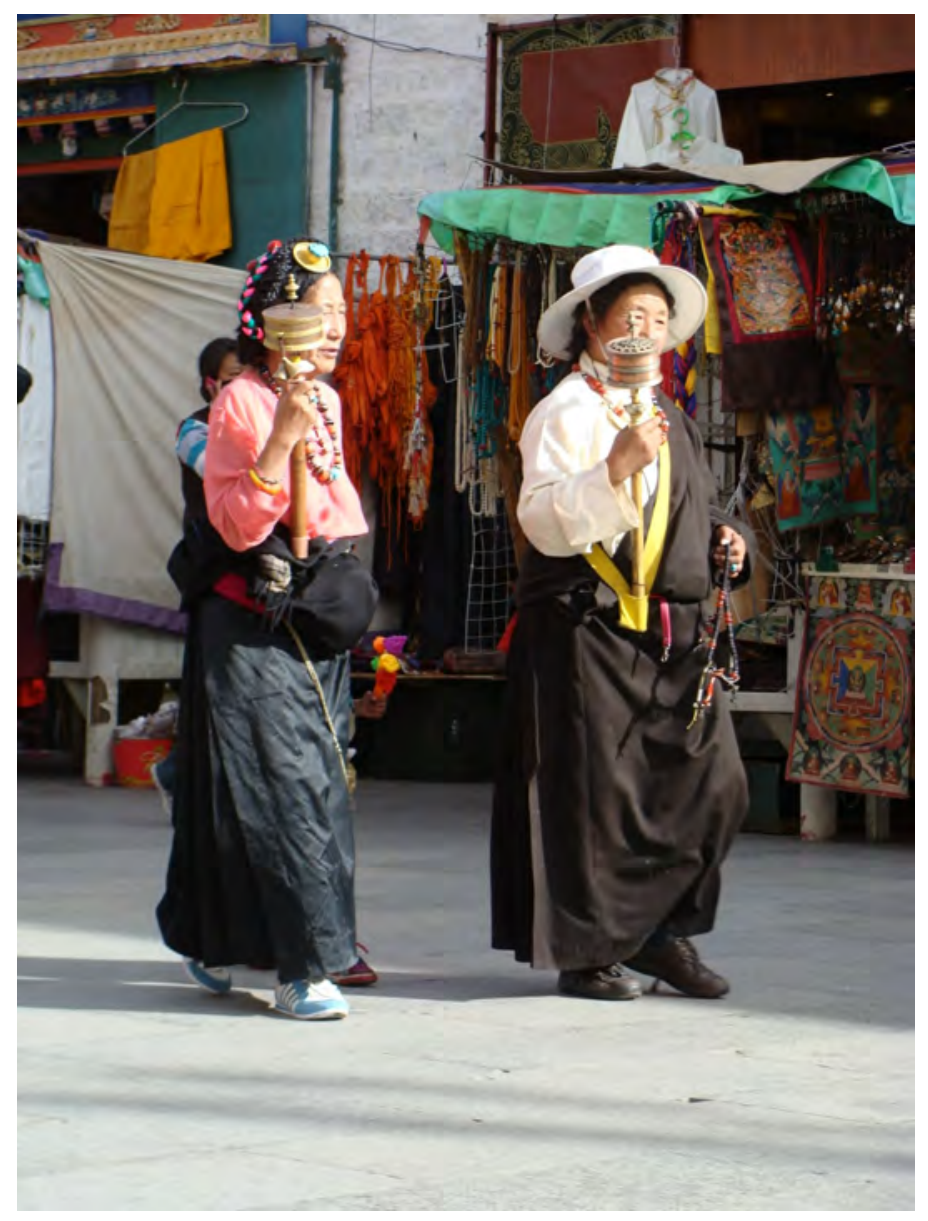

Photo 6. Private small prayer wheels, streets of Lhasa. Photo by Joanna Grela.

In addition to many representations of Avalokiteśvara's body and speech aspects, probably the greatest variety and richness of iconographic details can be found in the representations of his mind. The mental or mind aspect can be depicted as Avalokiteśvara's deity form, popular in the 18th century Refuge Trees (tshogs zhing), which in the Tantric model corresponds to the external level of the Three Refuges, i.e. the Sangha Jewel. It can also assume a variety of a meditational or tutelary deity (Skt. iștadevatā. Tib. yid dam) forms, which correspond to the second Jewel of the internal level of Three Refuges, that is the second of the Three Tantric Roots, developed in the second part of this paper. 


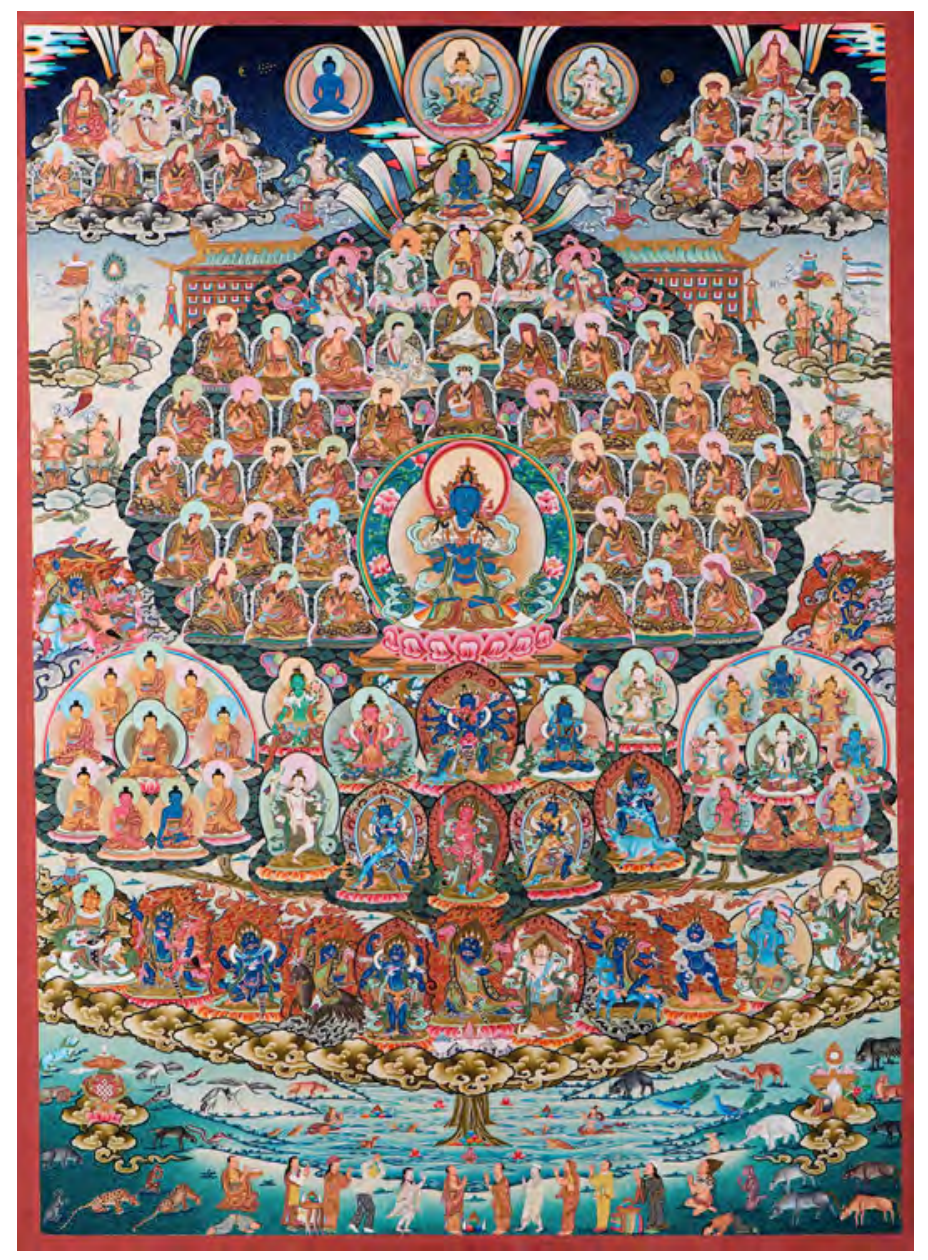

Photo 7. Bikash Lama, Kagyu Mahāmudrā Refuge Tree. Source: https://lotuswithin.com/product/karma-kagyu-refugee-tree/ Avalokiteśvara is shown in the middle right section of the above Refuge Tree. 


\section{List of abbreviations:}

ITJ - a manuscript from the Aurel Stein Collection, British Library, London.

Or - a manuscript from Oriental Collections, British Museum, London.

PT - a manuscript from the Collection Pelliot tibétain, Bibliothèque Nationale de France, Paris.

\section{Bibliography}

Bacot, J., Thomas F. W., Toussaint Ch. 1940. Documents de Touen-Houang relatifs à l'histoire du Tibet, Paris : Librairie Orientaliste Paul Geuthner.

Bsod nams rgyal mtshan. 1966. Rgyal rabs gsal ba'i me long. B. I. Kuznetsov (ed.), Leiden: E.J. Brill; English translation: Sakya Sonam Gyaltsen. 1996. The Clear Mirror. A Tibetan Account of Tibet's Golden Age, trans. T. McComas, Lama Choedak Yuthok, Ithaca, NY: Snow Lion Publications.

Fingesten, P. 1951. Toward a New Definition of Religious Art. "College Art Journal, Vol. X, No. 2. After: Gordon, A. K.. 2002. Tibetan Religious Art, New York: Dover Publications, Inc, pp. vi-viii.

God and King: The Devarāja Cult in South Asian Art and Architecture. 2005. A. R. Sengupta (ed.), New Delhi: National Museum Institute.

ITJ 0750.

Kapstein, M. 1992. Remarks on the Mani bKa'-'bum and the Cult of Avalokitesvara in Tibet, in: Tibet Buddhism: Reason and Revelation, S. D. Goodman and R. M. Davidson (eds.). Albany: State University of New York Press, pp. 57-93.

Kapstein, M. 200o. The Tibetan Assimilation of Buddhism: Conversion, Contestation, and Memory. New York: Oxford.

Kollmar-Paulenz, K. 2014. Kleine Geschichte Tibets. München: Verlag C.H. Beck.

Laird, Th. 2007. The Story of Tibet: Conversations with the Dalai Lama. New York: Grove Press.

Maṇi bka' 'bum. 1991. Xining.

Macdonald, A. W. 1984. Religion in Tibet at the Time of Srong-Btsan Sgam-Po: Myth as History. In: Tibetan and Buddhist Studies Commemorating the 2ooth Anniversary of Birth of Alexander Csoma de Körös, L. Ligeti (ed.). Budapest. Vol. 2, pp. 129-141. 
Or 8212.

PT $7 \mathrm{a}$.

PT 240.

PT 1286.

PT 1287.

PT 1288.

Segarra, A. 2007. Du Singe au Signe ou la figure du Trickster à travers les deux principaux personnages du Rāmāyaṇa et du Xìyóu jì : Hanuman et Sun Wukong. Clermont-Ferrand : Université Blaise Pascal.

The Old Tibetan Annals. An Annotated Translation of Tibet's First History. 2010. transl. B. Dotson. Wien: Verlag der Österreichischen Akademie der Wissenschaften.

Yü, Ch.-F. 1994. Guanyin: The Chinese Transformation of Avalokiteshvara. In: Latter Days of the Law : Images of Chinese Buddhism, 850-185. M. Weidner (ed.). Lawrence: Spencer Museum of Art, the University of Kansas, in association with University of Hawaii Press, pp. 151-182.

\section{Internet sources}

https://bobthurman.com/buddhism-101-tibets-dalai-lama-ep-110/dalai-lam a-alex-grey/ Accessed 2019.12.11

https://lotuswithin.com/product/karma-kagyu-refugee-tree/ Accessed 2020.03.11 